\title{
Was Alexander Hamilton a Machiavellian Statesman?
}

\author{
Karl Walling
}

Many important scholars have seen significant similarities in the political thought of Alexander Hamilton and Niccolo Machiavelli, but the only two references to Machiavelli in Hamilton's papers suggest deep misgivings about the kinds of politics we now call Machiavellian. This essay attempts to clarify Hamilton's ambiguous relation to the sage Florentine by focussing on the problem of waging war effectively and remaining free at the same time in the thought of both statesmen. Although Hamilton understood at least as well as Machiavelli the necessity of dynamic virtù in princes and civic virtue in free citizens, he sought to establish a new order of the ages, a republican empire, which would supply an effectual moral alternative to the genuine Machiavellian regimes of his day.

Was Alexander Hamilton a Machiavellian statesman? Many scholars of weight and stature seem to think so. Gerald Stourzh suggests that Hamilton followed Machiavelli in stressing the primacy of foreign over domestic policy. J. G. A. Pocock sees Hamilton as an advocate of a military and commercial empire whose dynamic virtù posed a severe threat to republican virtue. Isaac Kramnick links Hamilton to the language of state-centered power (of imperium, potestas, gubernaculum, prerogative, and sovereignty) implicit in Machiavelli's Prince (but oddly enough, Kramnick says, not in the Discourses). Finally, Harvey C. Mansfield, Jr., suggests that (as Publius) Hamilton partook in the modern effort to tame Machiavelli's prince without declawing him. Hamilton republicanized Machiavelli's prince to make him safe and useful to American freedom. ${ }^{1}$

Nathan Tarcov, Harvey C. Mansfield, Jr., Forrest McDonald, Robert Scigliano, and Michael and Catherine Zuckert supplied much needed advice for revising this essay. The Earhart Foundation supplied generous financial assistance.

1. Gerald Stourzh, Alexander Hamilton and the Idea of Republican Government (Stanford: Stanford University Press, 1970), pp. 132-45; J. G. A. Pocock, The Machiavellian Moment: Florentine Political Thought and the Atlantic Republican Tradition (Princeton: Princeton University Press, 1975), pp. 528-33; Isaac Kramnick, "The 'Great National Discussion': The Discourse of Politics in 1787," William and Mary Quarterly, 3rd ser., 45 (January 1988): 24; and Harvey C. Mansfield, Jr., Taming the Prince: The Ambivalence of Modern Executive Power (New York: Free Press, 1989), pp. 247-78. 
For all that has been said or implied about Hamilton's Machiavellianism, however, there are only two references to Machiavelli in Hamilton's collected papers. Each is quite critical of some of the imperialistic and duplicitous politics commonly associated with Machiavelli-politics which Hamilton believed were put into practice by the revolutionary republic in France and its ministers in America. ${ }^{2}$ These criticisms call for a greater effort to understand Hamilton's ambiguous relation to Machiavelli than has appeared so far. A useful beginning is to focus on the enormous difficulty of waging war and remaining free at the same time, a theoretical and practical problem which received considerable attention from both Hamilton and Machiavelli. Part I of this essay suggests that Hamilton was most like Machiavelli in calling for a strong national government headed by an energetic executive who could enable Americans to depend upon their own arms and virtue in time of war. Part II suggests that Hamilton surpassed Machiavelli in addressing the difficulty of waging war and remaining free at the same time. His new modes and orders called for financing war without crime and waging war without transforming America into a garrison state ready to conquer the world. Contemporary scholars have sometimes portrayed America as some kind of Machiavellian republic and Hamilton as some kind of Machiavellian prince. In contrast, Part III reveals that Hamilton's new order of the ages was designed to supply an effectual moral alternative to the Machiavellian practices of the Old World, and the genuine Machiavellian republic which arose from the ruins of the ancient regime in revolutionary France.

\section{I}

To understand Hamilton as he understood himself, one must begin at General Washington's field headquarters during the War for Independence in September 1780 when Hamilton was his principal confidential aide and a lieutenant colonel at the ripe old age of twenty-three. Hamilton was frequently responsible for

2. Rufus King to Alexander Hamilton, 14 July 1798, n 2; Relations with France, 1795-1796; and The Stand, No 1,30 March 1798, in The Papers of Alexander Hamilton, ed. Harold G. Syrett (New York: Columbia University Press, 1961), 19: 523-24, 21 : 382, and 22: 1-2. Hereafter all citations from Hamilton's Papers will be by volume and page number, e.g., Papers, 19: 523-24, etc. 
communicating on Washington's behalf with the state governments and the Continental Congress. A letter which the young colonel wrote from Washington's headquarters to James Duane, a friend who was serving in Congress, is nothing less than a military briefing on the necessity of immediate constitutional and administrative reform to win the war. It addresses all the militarypolitical "defects of our present system, and the measures necessary to save us from ruin." As Edmund Cody Burnett, the great historian of the Continental Congress observed, "It was a long way from 1780 to 1787 , but it would seem to have been directly, perhaps chiefly, from this implantation by Hamilton that the Federal Convention of 1787 actually grew." 3 To be sure, the lessons of the war were not the only subjects of the Convention's deliberations. Nonetheless, it began through the efforts of a tough-talking young colonel to save his country from ruin at a time when independence had not yet been won, and the liberty it was meant to secure was very much in doubt.

The doubtful character of the American cause is essential to understand the briefing. The army was starving - again! Hamilton feared another winter like the one he had experienced with the soldiers at Valley Forge, where they died of disease, hunger, and cold at the rate of over four hundred a month. All told, as many as twenty-five hundred soldiers, or about a fourth of Washington's command, may have perished in the six months the army spent in the camp. Largely because of its disorganization, Congress had left the post of quartermaster general vacant during the three coldest months of that ordeal. Not surprisingly, the soldiers tended to blame Congress for their accumulated sufferings. There was a grave danger that the soldiers would become "a mob, rather than an army." They were without "clothing, without pay, without provision, without morals, without discipline." The order of terms in this sentence is important. Hamilton progressed from the necessities of soldiers to their virtues, and implied that the latter were succumbing to the former. "We begin to hate our country for its neglect of us," he told the congressman, and "the country begins to hate us for our oppressions of them. Congress has long since been jealous of us; we have lost all confidence in

3. Hamilton to James Duane, 3 September 1780, Papers, 2: 401, and Edmund Cody Burnett, The Continental Congress (New York: Macmillan, 1941), p. 487. 
them, and give the worst construction to all they do. Held together by the slenderest of ties we are ripening for a dissolution. ${ }^{14}$ Without immediate support, he warned that a rebellious army might even turn its weapons on Congress. Then, the cause of the war would surely be lost.

American liberty depended on soldiers who were loyal to Congress and willing to fight. Such soldiers are the practical equivalent of Socrates' noble dogs, who are gentle toward their fellow citizens and fierce toward enemies. It was "vain to make apologies" to soldiers who had no food, weapons, or shoes. Congress might be forgiven for failing to provide for the army at the beginning of the war, when no one had any experience with this task, but after five years, there was no excuse for neglecting those who had suffered most for American liberty. Consequently, even the officers "were out of humor" with Congress. The "worst of evils," a "loss of our virtue," seemed imminent. Hamilton added bitterly, "I hate Congress-I hate the army-I hate the world-I hate myself." Not only the army's spirit, but his own had reached the bottom of despair. ${ }^{5}$

We are not accustomed to hearing Hamilton say much about virtue, much less to him calling the loss of virtue the worst of evils. Perhaps this is because in recent years we have been habituated to a simplistic conception of a term which, after all, is one of the most complicated in political and ethical theory. ${ }^{6}$ Republican virtue cannot simply mean altruistic sacrifice of private interest, or jealous opposition to power based on ever-vigilant scrutiny of those who possess it, as one might presume if one focussed simply on the thought of Hamilton's opponents. They elevated jealousy, which is normally considered a vice, into a virtue. ${ }^{7}$ Republican virtue

4. Duane, Papers, 2: 406. See also Howard Peckham, The War for Independence (Chicago: University of Chicago Press, 1958), pp. 82-85.

5. See Hamilton to Colonel John Laurens, 30 June and 12 September, 1780, Papers, 2: 348, 428; and Plato's Republic, trans. Allan Bloom (New York: Basic Books, 1968), 375a.

6. See, for example, Gordon Wood's Creation of the American Republic (New York: W. W. Norton, 1969), pp. 65-70.

7. See Thomas Jefferson's Kentucky Resolutions, The Portable Jefferson, ed. Merrill D. Peterson (New York: Viking Press, 1985), p. 288, and Hamilton's discussion of jealousy as a vice in Federalist, No. 1, in The Federalist, ed. Jacob E. Cooke (Middletown, CT: Wesleyan University Press, 1961), p. 5. Hereafter all citations from The Federalist will be by essay and page number, e.g. Federalist 1:5. 
must include not only the devotion of Brutus in opposing internal dangers to liberty, but also the stubbornness of the Roman soldiers who opposed Hannibal, the greatest external danger to Roman liberty. If so, republican virtue must also require the virtù, or resourcefulness and determination of Fabius and Scipio, the generals who led Rome's armies to victory in their mortal struggle with Carthage. This was certainly Machiavelli's view. He argued that not only the virtues, but also the "sins of the people are caused by their princes" because (as Lorenzo de Medici said) "'on the ruler all eyes are turned."

Like Machiavelli, Hamilton blamed the sins of the American people on the sins of their government. Before the Revolution began, he sounded very much like Machiavelli. "Contests for liberty," he claimed, "have ever been found the most bloody, implacable and obstinate. The disciplined troops Great Britain could send against us are but few. Our superiority in number would overbalance our inferiority in discipline. It would be a hard, if not an impracticable task to subjugate us by force." Experience would soon teach Hamilton that he had overestimated America's actual strength. The advantages of spirit and numbers do not count for much unless a nation has the kind of government which can draw on them and employ them with effect, and if it lacks such a government, it may not be able to sustain such spirit. After five years of war, Great Britain had managed to keep the odds at least even with "little more than fourteen thousand effective men." Nothing but a "GENERAL DISAFFECTION of the PEOPLE, or MISMANAGEMENT in their RULERS" could account for the inability of the confederation to win the war. ${ }^{9}$ Hamilton dared not admit the former alternative, and therefore focussed on the sins of the rulers - as the cause of the former. To be sure, Hamilton had a very low tolerance for platitudinous assertions that disinterested virtue was the foundation of republican government. Nonetheless, he meant to build public-spirited virtue on the solid, not necessarily

8. Discourses on the First Decade of Titus Livius, in Machiavelli, the Chief Works and Others, trans. Allan Gilbert (Durham: Duke University Press, 1989), 3, 29: 492-93.

9. A Full Vindication, December, 1774, Papers, 1: 54; The Farmer Refuted, February 1775, Papers, 1: 155-56; Continentalist 3, 9 August 1781, Papers, 2: 662-63; Discourses, 2. 2: 330-31; 16: 363; and The Prince, trans. Harvey C. Mansfield, Jr. (Chicago: University of Chicago Press, 1984), 5: 20. 
low, but certainly effective grounds of public confidence and private interest.

Like Machiavelli, Hamilton deplored depending on the uncertain arms and virtue of others, including the states, in no small part because such dependence undermined confidence in the ability of Congress and the army to support themselves and take the initiative against the enemy. Hamilton stressed a decline of confidence in Congress within the army, among investors (whose support was necessary to finance the war), and among the people at large. There was a "universal sentiment" that the existing government was a "bad one," and incapable of waging the war effectively. Something had to be done to "revive the hopes of the people, and give a new direction to their passions." 10 No one would risk as much as might be necessary to win the war unless Congress proved it was worthy of the enormous trust which had been placed in it. This would never be possible if Congress continued to rely upon the states to support the army. The "source of all our military misfortunes," Hamilton claimed, was the "fluctuating state of our army." Nothing contributed to the ebb and flow of recruiting and retention more than dependence upon the states for supplies, revenue, and troops. This was "too precarious a dependence because the states," particularly those situated in a calm theater of the war, "will never be sufficiently impressed by our necessities." Experience revealed that "each will make its own ease a primary object, the supply of the army a secondary one." The colonel spoke for the whole army when he claimed that "we feel the insufficiency of this plan, and have reason to dread under it a ruinous extremity of want."11

Hamilton wrote his briefing before the Articles of Confederation had been accepted by all the states. The preconfederation Congress never had "any definite power granted them and of course could exercise none." It lacked the legitimacy which arises from a formal delegation of powers and "could do nothing more than recommend," but after years of frustration, the colonel found this common excuse for delay and stagnation inexcusable. "The manner in which Congress was appointed," in

10. Duane, Papers, 2: 417, and Discourses, 3. 33: 502-03.

11. Duane, Papers, 2: 406. See also Federalist, 15: 94-98; The Prince, 1: 5-6; 24: 97; and Discourses, 3. 11: 458. 
an extraconstitutional emergency when American liberty was at stake, "and the public good required" that Congress should have done what Machiavelli claimed the Romans did when they appointed a dictator: Congress should have considered itself "vested with full power to preserve the republic from harm." Congress had already acted according to this Machiavellian principle by declaring independence, forming an army and a navy, establishing diplomatic relations and alliances, etc. All these "implications of complete sovereignty were never disputed" and should therefore have served as the "standard of the whole conduct of the Administration." Until the Articles of Confederation were drafted and accepted, all of Congress's powers were "discretionary powers, limited only by the object for which they were given. ... in the present case, the independence and freedom of America." After its first moments of boldness, however, Congress had grown accustomed to what both Hamilton and Machiavelli considered the vice of "doing right by halves, and spoiling a good intention in the execution." Since Congress had already acted on the assumption of complete sovereignty, it had to resume its discretionary powers and assert control over every power necessary to support the war. ${ }^{12}$

Yet this plan might have been "thought too bold by the generality of Congress" to be practical at this stage of the war. Moreover, although the Articles of Confederation formalized some of the necessary war powers, the Articles themselves were half-measures which did not rise to the necessities implied in declaring independence. They might even provide additional excuses for doing nothing, as in fact they would for the rest of the war. Perhaps worst of all, the half-measures might force Congress to choose between violating the Articles to avoid defeat or risking defeat to remain faithful to the constitutional rule of law. Both Hamilton and Machiavelli believed well-founded republics should avoid this dilemma as much as possible because it tends to undermine the rule of law itself. To avoid this dilemma, nothing

12. See Duane, Papers, 2: 401, 406-407; Hamilton to Marquis de BarbeMarbois, 7 February 1781, Papers, 2: 554; Hamilton's "Unsubmitted Resolution calling for a Constitutional Convention," July 1783, Papers, 3: 421; Burnett, Continental Congress, pp. 452-56, 484-85; and Discourses, $1.27: 254 ; 1.34: 269 ; 2$. 15 : $360 ; 3.24: 485-86$. 
was more important than a constitutional convention with plenipotentiary authority to grant Congress "complete sovereignty in all that relates to war, peace, trade, finance, and the management of foreign affairs." Consistent with Machiavelli's advice, it was essential to make the resumption of sovereign powers unambiguously legitimate by constitutionalizing it. ${ }^{13}$

Just as Hamilton criticized Congress for depending on the uncertain arms and virtue of the states, he also criticized it for depending too much on foreign allies. "Too sanguine expectations from Europe have unintentionally relaxed our efforts, by diverting a sense of danger, and begetting an opinion that the inequality in the contest would make every campaign the last." Congress ignored the energy which both Hamilton and Machiavelli believed belonged to a single state, like England, with a unified command against many allied states. Moreover, every rumor of a foreign loan, a secret arms shipment, or the influence of the European powers in seeking a negotiated settlement diminished the incentives in Congress to procure supplies from domestic sources. "Finding the rest of Europe either friendly or pacific," Congress "never calculated the contingencies which might alter that disposition." For example, both America and France were bound by treaty not to make a separate peace, but for all the influence of the philosophes, France was in the war to hurt England and help itself. During the decisive campaign of the war, the siege of Yorktown, the French army was actually larger than the force of Continentals which Washington managed to mobilize for the siege, and the siege depended on the French navy blockading the British. Precisely because victory depended on the French, the costs of betrayal could have been catastrophic for the Revolution. If Congress did not wish to risk such a disaster, then Hamilton argued there was only one viable strategy. Congress would have to prepare for a long war which might have to be fought without any allies, or even against former allies. It would have to follow Machiavelli's advice and rely on its own arms and virtù. As Machiavelli said in explaining why the princes of Italy had lost their states, "one should never fall in the belief you can find

13. See Federalist, 25: 162-63; Discourses, 1. 34: 267-69; 1. 45: 288-89; and Mansfield, Taming the Prince, pp. 255-57. 
someone to pick you up. Whether it does not happen or happens, it is not security for you because the defense was base and did not depend on you. And those defenses are good, are certain, and are lasting, that depend on you yourself and your virtue."14

Yet self-reliance in Congress would not be sufficient to restore public confidence. The wartime government had no separation of powers, and this fact had much strategic and moral importance. Congress ran every aspect of the war, but Congress was "properly a deliberative corps and it forgets itself when it tries to play the executive." Hamilton both exalted and criticized Congress when he said this. It was responsible to deliberate upon policy, which is perhaps the highest task of government, but incapable of executing policy against an enemy capable of opposing its resolutions. Its members did not serve long enough to learn how to run a nation at war. Frequent rotation made it extremely difficult for anyone to assume responsibility for the overall conduct of any part of the war effort. Consequently, Congress could never convince the people that it had the virtù to dominate the enemy..$^{15}$

Hamilton believed the only way to resurrect public confidence was to form regular executive departments headed by individuals who could supply method and system to the war effort. Writing to Robert Morris, who had just been appointed superintendent of finance, Hamilton argued that "an administration by single men" was the "only resource we have to extricate ourselves from the distresses, which threaten the subversion of our cause. . . It is palpable that the people have lost all confidence in our public councils." Moreover, friends in Europe shared the "same disposition." Neither the people at home nor allies abroad would give "half the succors to this country while Congress holds the reins of administration" as they would grant if administration were "entrusted to individuals of established reputation and conspicuous for probity, abilities, and fortune." Winning the war therefore required an effort to "blend the advantages of monarchy and a republic in our constitution." ${ }^{16}$

14. Continentalist 3, 9 August 1781, Papers, 2: 663-64; The Prince, 24: 97; and Discourses, 2. 4: 335-39.

15. See Duane, Papers, 2: 403-04; Hamilton to George Clinton, 13 February 1778, Papers, 1: 425; and Burnett, Continental Congress, pp. 317, 503, 592, 605, 607.

16. Duane, Papers, 2: 405; Hamilton to Robert Morris, 30 April 1781, Papers, 2: 604-605. 
Hamilton's controversial speech of 18 June 1787 should be interpreted in light of these remarks. In his letter to Duane, Hamilton was not talking about instituting a monarchy, and certainly not an hereditary one. Instead, he was discussing the advantages enjoyed by monarchies and republics in time of war. According to Montesquieu, combining the strategic advantages of large monarchies (strength and numbers) with the political advantages of small republics (liberty and spirit) is the fundamental objective of all republican federations. Hamilton was therefore talking about how to make federal theory work in practice. The problem with federal theory, at least as developed by Montesquieu, is that it never explained how federations can have the advantages of monarchy, which literally means the rule of one, without one person actually governing with respect to those matters where one executes policy best. "Of all the cares and concerns of government," Hamilton would later argue, "the direction of war most peculiarly demands those qualities which distinguish the exercise of power by a single hand. The direction of war implies the direction of the common strength; and the power of directing and employing the common strength, forms an usual and essential part in the definition of executive authority." The absence of a unitary executive goes far to explain why federations never really lived up to Montesquieu's expectations. As Machiavelli explained, they were far too slow and indecisive to compete against large unitary states under the direction of one person-unless of course they fell under the hegemony of a dominant republic, as happened when Rome transformed the Italian confederation into an empire subject to its will. When this happens, however, the means by which republics seek to prepare for war becomes the instrument of their own enslavement. ${ }^{17}$

Hamilton understood this great dilemma of republican federations better than any of the Founders, but like Machiavelli, he also understood the moral and strategic advantages of republics in a manner which is frequently neglected by contemporary scholars. In an effort to persuade Duane to lobby for a congressional power to tax to support the war, Hamilton asserted that "Where the public good is evidently the object, more can be

17. Federalist, 74: 500; The Spirit of the Laws, trans. Thomas Nugent (New York: Hafner, 1949), 9. 1: 126; and Discourses, 2. 7: 336-39. 
expected in governments like ours than in any other. The obedience of a free people to general laws however hard they bear is ever more perfect than that of slaves subject to the arbitrary will of a prince." Later, at the Federal Convention, he claimed that one reason a "free government is to be preferred to an absolute monarchy" is the "tendency of the Free Government to interest the passions of the community in its favor," and to "beget public spirit and public confidence." Both Machiavelli and Hamilton understood that a free people sacrifice for their country, as Tocqueville would later say about public spirit in America, almost out of greed. The difference is that Hamilton and Machiavelli suggested that this patriotic greed was directed at least as much by the ambitions republican citizens have for their children as those they have for themselves. Consistent with Tocqueville and Abraham Lincoln, however, they would probably agree that the spirit of republicans arises much less from reverence for the past than hopes for the future. ${ }^{18}$

Yet to get citizens to fight, they must believe that victory is possible. Hamilton argued that there was "so rooted a diffidence of the government, that if we could be assured the measures of Congress would be dictated by the most perfect wisdom and public spirit, there would still be a necessity of change in the forms of administration to give a new spring and current to the passions and hopes of the people." Winning the war required a separation of powers with an executive capable of preparing for the predictable necessities and responding to the unpredictable fortunes of war. At the beginning of the war, Hamilton copied a maxim from Demosthenes on the back pages of his military pay book which explains precisely what he wanted in a wartime executive: "As a general marches at the head of his troops," Demosthenes advised, "so too ought wise politicians, if I dare use the expression, to march at the head of events; insomuch as

18. See Duane, Papers, 2: 413; Hamilton's "Notes Taken at the Federal Convention," 1-26 June 1787, Papers, 4: 163; Hamilton's "Remarks at the Federal Convention," 26 June 1787; Papers, 4: 218; Hamilton's "Remarks at the New York Ratifying Convention," 28 June 1788, Papers, 5: 125; Discourses, 2. 2: 329, 333-34; Alexis de Tocqueville, Democracy in America, trans. George Lawrence (New York: Harper, 1966), 1: 237; and Lincoln's speech to the 166th Ohio Regiment, 22 August 1864, in The Political Thought of Abraham Lincoln, ed. Richard N. Current (New York: Bobbs-Merrill, 1967), 330. 
they ought not to await the event to know the measures to take; but the measures which they have taken ought to produce the event." Next to this maxim, Hamilton copied another from Longinus: "Where attack him it will be said? Ah Athenians, war, war itself will discover you his weak sides if you seek them.'" Hamilton added his own appreciation, "sublimely simple," to these ancient precepts of military wisdom. Their advice was broadly consistent with Machiavelli's. Especially in time of war, Fortuna favors the bold and impetuous who subject her to overwhelming necessities which prevent any effectual resistance. Hamilton understood that no republic can dominate Fortuna or generate public-spirited citizens without unity and a substantial degree of independence in the executive, the prerequisites of virtù in that office. ${ }^{19}$

If executive departments were established, they would be essential to two of Hamilton's extremely innovative plans for winning the war: founding a national bank and reorganizing the army. Like Machiavelli, Hamilton meant to restore the public spirit required for victory, but unlike Machiavelli, he meant to fund the war without crime and support the army without terrorizing the people or turning America into a garrison state bent on world conquest.

By the time Hamilton wrote his briefing, the continental currency had collapsed. Congress printed money to pay the army and its creditors, and then hoped the states and foreign loans would supply the hard cash to back up its paper. The hopes never materialized enough to prevent the depreciation of the currency, and consequent stagnation of the economy. Substantial portions of America were even reduced to a barter economy. ${ }^{20}$

19. Pay Book, Papers, 1: 390; Duane, Papers, 2: 404; Hamilton to Morris, Papers, 2: 605; The Prince, 25: 99-101; Machiavelli's Art of War, trans. Ellis Farneworth (New York: Da Capo, 1965), 7: 202-04, martial maxims \# 1, 6, 24; and Carl von Clausewitz, On War, ed. Anatol Rapoport (New York: Penguin, 1985), 3. 6: 259 .

20. Burnett, Continental Congress, pp. 419, 426-27, and Donald F. Swanson, The Origins of Hamilton's Fiscal Policies (Gainesville, FL: University of Florida Press, 1963), pp. 35-37. 
With a worthless currency, Hamilton knew it was virtually impossible to produce the goods or raise the revenue necessary to prosecute the war with vigor. In contrast to Hamilton, Machiavelli denied that gold, or wealth in general, is the "sinews of war; for gold is not enough to find good soldiers, but good soldiers are quite enough to find gold." Yet Machiavelli meant that good arms can always get gold by exacting tribute from foreign neighbors, that is, by stealing it from the enemy. He was well aware that nothing undermines public spirit more than a government obliged to rob its own citizens. Likewise, both Hamilton and Washington deplored the desperate occasions when they were obliged to confiscate private property for military use. They knew that their tactical expedients often contradicted their strategic necessities: every horse and shoe they took cost the army the support of citizens deprived of their property. Yet their objections to confiscating property were not confined to its tendency to undermine public spirit. The Revolution, after all, was being waged to secure American rights, including the right to property. The tactical expedients of the army were therefore in grave tension with the moral objectives of the Revolution. ${ }^{21}$

Deserving victory required finding a way to raise money without stealing it. Both liberal principle and the Machiavellian necessity to hold the support of the people therefore required Hamilton to pay attention to the "revolution in the system of war" produced by the "science of finance." Washington's Fabian strategy simply could not succeed without coming to terms with that science. "'Tis by introducing order into our finances-by restoring public credit - not by gaining battles that we are to attain our object," Hamilton wrote to Robert Morris. "'Tis by putting ourselves in the position to continue the war, not by temporary, violent and unnatural efforts to bring it to a decisive issue, that we shall in reality bring it to a speedy and successful one." Yet the strategic advantage of effective finance was also a moral advantage, and one that did not require superhuman sacrifices for the public good. The "signal merit of a vigorous system of national credit," Hamilton would later argue, is that it "enables a government to

21. See Hamilton to Major General John Sullivan, 7 July 1777, Papers, 1: 284; and Hamilton to Colonel Clement Biddle, 20 August 1780, Papers, 2: 380. 
support war without violating property, destroying industry, or interfering unreasonably with individual enjoyments." Without effective finance, a nation becomes prey to "every enterprising invader" or must resort to "oppression of the citizens" through high taxes and confiscatory policies. By means of sound credit, however, war "becomes less a scourge" and "loses a great portion of its calamity," at least for the citizens who must ultimately pay for it. Sound credit, backed by provisions for funding the national debt, would enable the present to borrow from the future in time of danger in order to secure the liberty of posterity without robbing the present of its rights. ${ }^{22}$

Contrary to the claims of many contemporary historians, who suggest Hamilton sacrificed public-spirited virtue to virtù, Hamilton's credit policies were also designed to produce publicspirited citizens who would risk their lives and the property on behalf of the their liberty. ${ }^{23}$ Hamilton claimed it was the business of the government to inspire "confidence by adopting the measures I have recommended." Under a "good plan of executive administration" capable of putting his proposals in a "train of vigorous execution," there would be a "new spring to our affairs; government would recover its respectability," and "individuals would renounce their diffidence." "All we have to fear," Hamilton claimed, is what Franklin Roosevelt later called fear itself, "a general disgust and alarm" which could lead the army to disband, or the people to clamor "for peace on any terms," including the loss of their liberty in the struggle with England. If Morris proposed and Congress adopted a national bank offering investors a significant return for their risk, then Hamilton believed public and private credit could be united, and multiplied. In a crisis, Congress might borrow from the bank to help pay for the war, as the British did from the Bank of England and as all successful modern republics had done from the time of Renaissance Venice. Nonetheless, the fundamental purpose of the bank was not fund the war, at least not directly. Like the notes Hamilton would later

22. See Discourses, $1.37: 272 ; 2.2: 333 ; 2.10: 349-51$; and The Prince, $19: 72 ; 21$ : 91. See also Hamilton to Morris, Papers, 2: 606, his Defense of the Funding System, July 1795, Papers, 19: 53-54; Federalist, 8: 47; and Harvey Flaumenhaft's The Effective Republic, Administration and Constitution in the Thought of Alexander Hamilton (Durham, NC: Duke University Press, 1992), p. 19.

23. See, for example, Pocock, Machiavellian Moment, p. 529. 
issue to fund the national debt as secretary of the treasury, the bank notes would supply a substitute for money, which could be traded and used to spur industry. By supplying a trustworthy medium of exchange, the notes would resurrect public confidence, help investors to produce the material necessary for a war economy, and produce profits which Congress could tax to fund the war and the confederation's enormous debts. ${ }^{24}$

The dependence of public spirit on effective finance was virtually unknown to Americans of Hamilton's time, and most contemporary scholars of the Founders therefore pay little attention to it. Yet Hamilton was not the only innovative statesman of his time to understand how the daring and resourceful virtù of a finance minister might influence the morals, or more accurately, the morale of his people. Jacques Necker, the minister of finance in France during the war, argued that a finance minister must "above all, by active and continual anxiety, excite confidence, that precious sentiment which unites the future to the present. . . . and lays the foundation of the happiness of the people. Then everyone will look on the contributions which are demanded of him, as a just assistance afforded to the exigencies of the state, and as the price of the good order which surrounds him, and the security which he enjoys." By such means, the minister may recall the "ideas of justice and patriotism" among the people, but if they lose their confidence, "private interest will be everywhere opposed to the public welfare." A "skillful administration," he claimed, has the "effect of putting in action those it persuades, of strengthening the moral ideas, of rousing the imagination, and of joining together the opinions and sentiments of men by the confidence it produces." For this reason, it could have the "greatest influence over the social virtues and morals." Necker therefore claimed it is the "fault of the administration," and especially its finance minister, "if these natural dispositions, so adapted to PATRIOTISM" are not produced by and attached to the government. ${ }^{25}$

24. Duane, Papers, 2: 414, and Morris, Papers, 2: 604-05, 631.

25. See Jacques Necker, A Treatise on the Finances of France, trans. Thomas Mortimer, 3 vols. (London: Logographic Press, 1787), 1: ix-xiii, xxii-xxiii, xciv; Donald F. Swanson and Andrew P. Trout, "Alexander Hamilton, 'the celebrated Mr. Necker,' and Public Credit," William and Mary Quarterly, 3rd. ser., 48 (July 1990): 424-30; and Forrest McDonald, Alexander Hamilton: A Biography (New York: Norton, 1979), pp. 135-36, 164-71. 
According to Machiavelli, those who mean to remodel a republic must keep up at least the semblance of old forms. Hamilton put this insight into practice in all his fiscal and monetary policies. On the one hand, those policies founded public spirit on the politically practicable basis of public confidence; on the other hand, they made fanatical devotion to a republic less necessary by establishing the economic foundations of overwhelming military power. The fundamental cause of Congress's difficulties in funding the war was the lack of specie in America. There was not enough specie to back Congress's paper. The specie supply would not increase because Congress established a bank. Yet if the notes were backed by a foreign loan and denominated in the old forms of pounds and shillings rather than worthless dollars, the people might believe the specie in the bank was as available as specie in the Bank of England. Then, the "illusion" of solidity would produce confidence in the bank notes. ${ }^{26}$ In time, perhaps, the credit bubble would burst, especially if someone without Hamilton's administrative skills managed it, but if it lasted long enough to fund the war, Americans would be free. This by itself would justify the risk. Yet Hamilton understood that the "real wealth" of a nation is not its specie, but its "labor and commodities." If the bubble could last beyond the end of the war, resuscitated credit could promote a new kind of economy of industrious increase, which is now the most important foundation of modern military power. Indeed, though it is often forgotten, Hamilton's famous Report on Manufactures was a response to a request from Congress (which was perhaps planted by friends of Hamilton) to make America self-sufficient in the industrial foundations of modern warfare. ${ }^{27}$

26. See The Prince 18: 70-71; Discourses, 1. 25: 252-53; Locke's Second Treatise, ed. Peter Laslett (Cambridge: Cambridge University Press, 1988), 415: 215; Hume's "Of the First Principles of Government," in Essays Moral, Political, and Literary, ed. Eugene F. Miller (Indianapolis, IN: Liberty Classics, 1985), p. 32; Hamilton's First Report on Public Credit, 9 January 1790, Papers, 6: 69; and McDonald, Hamilton, p.171.

27. Morris, Papers, 2: 616-20, 624; and Discourses 1. 25: 252; 1.47: 292. To trace the relation between the modern economy of increase through trade and credit to the economic foundations of modern military power, see The Prince, 16: 63 and 21: 91; Second Treatise, 42: 298; Hume's "Of Commerce," pp. 258-63; Adam Smith's Wealth of Nations, ed. R. H. Campbell et al. (Indianapolis, IN: Liberty Classics, 1979), 1: 463-64 and 2: 705-09, 781-88; Hamilton's Report on Manufactures, 
The second part of Hamilton's strategy to win the war was an effort to make America's potential energy kinetic. He meant to mobilize an entire nation for war in a manner which prefigured the nation at arms of the French Revolution, and Clausewitz's understanding of the strategic revolution produced by that political revolution. Like the Constitution he would later defend in 1787 , the strategy was meant to endure for ages. ${ }^{28}$ The first step was to replace the cumbersome method of gaining recruits through bounties for short term service with a draft for three years. This would not only increase the numbers of the army, but also give veterans time to train recruits to be effective soldiers. The second step was to establish a pension plan of half-pay for life for the officers corps. Although some in Congress feared pensions would corrupt the army by making it dependent on Congress rather than the states, Hamilton looked at such "corruption" as the foundation of national loyalty (and thus virtue) in the army. The pension would secure the "attachment of the army to Congress. ... We should then have discipline, an army in reality, as well as in name." Without such attachment, Hamilton was well aware that the army would be neither effective in the field nor safe to the liberties of the American people. ${ }^{29}$

The third step was the most revolutionary. Hamilton planned to enlist slaves in the South, and promise them their freedom

5 December 1791, Papers, 10: 230, 254-56, 259, 262-63, 291; Hamilton's Defense of the Funding System, 19: 53-54; and Edward Meade Earle's classic, "Adam Smith, Alexander Hamilton, and Friedrich List: the Economic Foundations of Military Power," in Makers of Modern Strategy, ed. Peter Paret (Princeton: Princeton University Press, 1986), pp. 217-61.

28. See Clausewitz, On War, 8. 3: 371-81; Peter Paret's "Clausewitz," in Makers of Modern Strategy; Earle (see note 27), Russel F. Weigley, Towards an American Army: Military Thought from Washington to Marshall (New York: Columbia University Press, 1962), pp. 10-29; Samuel P. Huntington, The Soldier and the State: The Theory and Practice of Civil Military Relations (Cambridge, MA: Harvard University Press, 1957), pp. 193-221; and John Fiske, The Critical Period in American History (Boston: Riverside Press, 1899), pp. 101-103.

29. Hamilton also wanted to rid the army of foreign officers whose presence tended to undermine the morale of American officers, but it was difficult to cashier them without offending American allies. Sometimes, it seems, the only way to follow Machiavelli's famous advice to get rid of mercenaries is to pension them. See Duane, Papers, 2: 409 410; Hamilton to George Clinton, 13 February 1778, Papers, 1: 149, Hamilton to William Duer, Papers, 1: 247; The Prince, 12: 4849; and Burnett, Continental Congress, pp. 312-313, 393, 444. 
with their muskets. Freedom would "secure their fidelity, animate their courage" and have a "good influence" on those who remained in bondage by "opening the door to emancipation." Their habits of obedience coupled with their new spirit of liberty might make them the most loyal and courageous soldiers America could produce. As the South became the primary theater of the war in the last years of the Revolution, such soldiers were at a premium because there were extremely few whites who could be pressed into service. Hamilton claimed that emancipation followed from both "the dictates of humanity and true policy." Together with John Jay, Hamilton founded the New York Society to Emancipate the Slaves. It had "no small weight" to Hamilton that employing this "unfortunate class of men" might open the door to freedom for all. He may therefore have disguised humanity as good policy. Speaking very soberly, or rather, in a manner calculated to inspire terror in the hearts of all slaveowners, he argued that if the southerners did not emancipate and arm their slaves, the "enemy probably" would. The "best way to counteract the temptations they hold," he claimed, would "be to offer them ourselves." 30

Hamilton's plan had no support from the agrarian aristocrats of the South, which is why it was not adopted. Nonetheless, the plan was consistent with Machiavelli's advice and prefigures the many social revolutions caused by war in American history. Just as the Romans found it necessary to grant greater freedom to the people in order to use them in their armies, Americans and all modern nations have found it impossible to wage war effectively without granting ever more freedom to the lowest orders of society. Modern revolutions made modern democratic (or mass) wars possible, but modern democratic warfare made modern mass democracy ever more necessary, if not even inevitable. The great question was whether the new form of democracy produced by the simultaneous revolutions in war and politics would produce freedom or despotism. ${ }^{31}$

Hamilton's end-of-the-war report on a military peace establishment was a remarkably far-sighted effort to ensure that the new mode of warfare remained compatible with free 
government. Both economy and prejudice seemed to favor a military organization based on citizen-soldiers in the militia, who appeared to be less expensive, and more effective and loyal than their presumed alternative, a standing army of mercenary soldiers who fought for pay. Hamilton, however, denied that a militia is less expensive than a small well-trained force because modern military power requires a productive economy, and thus a division of labor between soldiers and civilians. Training the militia to be effective would require great amounts of money and also decrease industry while the militia trained. Since wealth was the principal source of military power, the decrease in industry would ultimately make America less fit for war than reliance on professionals. On the basis of solid experience, Hamilton doubted that many citizens would be willing to train enough to merit the title of a well-regulated militia. In a nation devoted to the pursuit of happiness, the "militia would not long, if at all, submit to be dragged from their homes and families to perform the most disagreeable duty in time of profound peace." The effectual truth of modern commercial republics is that they require professional, reasonably well-paid soldiers because no one else in such republics is willing to spend a lifetime preparing for war. ${ }^{32}$

In contrast to Hamilton, Machiavelli stressed reliance on citizen-soldiers from the militia, but the moral significance of this difference has not yet been explored. As Machiavelli knew (because he was in charge of raising the Florentine militia), a militia composed of farmers and shopkeepers was unreliable. In 1512, 5,000 experienced (and hungry) Spanish mercenaries met 4,000 Florentine militiamen who had been trained (but were not led) by Machiavelli in a garrison at Prato, ten miles northwest of Florence. 6,000 other militiamen guarded Florence. The militia at Prato panicked and laid down their arms against the smaller, more disciplined force. In the next three weeks, as many as 5,000 militiamen and citizens at Prato fell victim to "the Spanish fury." The massacre destroyed the resolve of the Florentines, who quickly surrendered, and Florence was restored to the Medici. Reliance on the militia cost Florence its liberty, and Machiavelli his job in the Florentine Chancery and Council of Ten for War. Since he was

32. See Hamilton to John Dickenson, 25-30 September 1783, Papers, 3: 454; Federalist, 8: 47; Federalist, 24: 156-57. 
tortured soon after losing his job, Machiavelli certainly had good reason to regret relying on the militia. ${ }^{33}$

Instead of the Florentine militia, Machiavelli had something very Roman in mind when he called for a citizen army. In the Art of War, Machiavelli's interlocutor, Fabrizio, observed that Rome was "almost continually engaged in war, and obliged to choose some men who had served before, and others who were altogether raw." Although there were always "new men in this sort of levy," Machiavelli claimed that there were also "so many veterans that together" they made a "very good army." When the citizensoldiers trained, they were drilled by veterans of previous campaigns, who filled in for the most important element of any military organization, the non-commissioned officers. Roman citizens were therefore very close to the functional equivalent of a modern professional army. Machiavelli knew this kind of army must live by theft and therefore conquest and tribute because there are too few civilians left at home to support them. If a modern Philip of Macedon adopted his proposals, then Fabrizio claimed, he might "grow so powerful" that he could conquer them all (and unite Italy) in a few years. Then, his son, a new Alexander, might be able to "conquer the whole world." ${ }^{34}$

Hamilton did not believe Rome was an appropriate model for America. "All her maxims and habits were military, her government was constituted for war. Ours is unfit for it, and our situation [as a modern, free, commercial people] still less than our constitution, invites us to emulate the conduct of Rome, or to attempt to display an unprofitable heroism." In this context, Hamilton was trying to dissuade his fellow New Yorkers from imitating the Romans by conquering Vermont, which had seceded from the empire state. He was well aware that the heroic virtues of antiquity were dependent on some miserable vices which do not fit well in a society based on universal natural rights. Sparta, he later claimed, was little more than an "armed camp," and Rome was "never sated of carnage and conquest." ${ }^{35}$

33. Victor A. Rudowski, The Prince, an Historical Critique (New York: Twayne Publishers, 1992), pp. 77-78.

34. Weigley, 25; Hamilton to William Loughton Smith, 10 April 1797, p. 21: 40; Hamilton to Theodore Sedgewick, 2 February, 1799, p.22: 453; and The Art of War, I:35; VII:212.

35. Federalist, 8: 47; Hamilton's Remarks on an Act Acknowledging the Independence of Vermont, 28 March 1787, Papers, 4: 140; and Flaumenhaft, The Effective Republic, p. 19. 
Any attempt to replicate the effectiveness of ancient citizen armies would require imitating their ferocious imperialism or transforming America into a garrison state, or both, but how could America wage war effectively without risking these dangers? Hamilton's proposal was a peacetime military establishment of a little over three thousand officers and men. Unlike the militia, the professionals would have the time to train to become effective soldiers; unlike mercenaries; the professionals would be citizens, with a stake in their country's liberty. As Machiavelli himself argued, such a stake would go far to secure their loyalty to the republic. ${ }^{36}$ Hamilton was among the first to propose founding a military academy to train future officers in a rigorous program of science, technology, and the principles of war. Career officers would also be cycled through the military academy quite frequently for refresher and enhancement training. Except during an emergency, however, the professional's primary mission was not to wage war. Instead, it was to teach other citizens to wage war. If the army were capable of almost infinite expansion, citizens could be classified and serve in various kinds of reserve and militia units, which Hamilton aimed to maintain at at least four different levels of readiness. Then, only the professionals and those in an elite reserve corps of "train bands" would spend much time in service, but all could be mobilized, and trained very quickly according to the degree and kind of military threat. For this reason, Hamilton paid almost as much attention to noncommissioned as to commissioned officers. He "always" wanted to have enough professional NCOs on hand to train a reserve force of 50,000 men, that is, a force sixteen times as large as the professional army! As storm clouds gathered, more civilians could be drawn into service; as they dissipated, the nonprofessionals could be released from duty. Expenses could be kept low, but only if the professionals were kept at the highest level of training and readiness. Americans might then combine the skill of professionals with the numbers and spirit of republican citizens without impoverishing themselves or turning their country into an armed camp. ${ }^{37}$

36. Discourses, 1, 43: 286.

37. See Discourses, 1, 43: 286; Hamilton's draft of Washington's "Speech to Congress," 10 November 1796, Papers, 20: 384-85; the Report on a Military Peace Establishment, Papers, 3:391-92; and various proposals for reorganizing the military during the Quasi-War at Papers, 21: 83, 342-43, 362, 486; Papers, 22: 389-90; and Papers, 24: 70, 310. 
Though rarely given credit for it, Hamilton thought a great deal about the dangers war poses to free government, and especially to the spirit of liberty in the people. "Safety from external danger," Hamilton claimed, "is the most powerful director of national conduct. Even the ardent love of liberty will, after a time, give way to its dictates." The casualties of war are not limited to the battlefield. "The violent destruction of life and property incident to war - the continual effort and alarm attendant on a state of continual danger, will compel nations most attached to liberty, to resort for repose and security, to institutions, which have a tendency to destroy their civil and political rights." To some extent, this insight simply describes the movement from the state of nature or war into civil society, but the problem is that necessity may panic the people, or their representatives, to such an extent that they do not stop at a point safe to their civil and political rights. "To be more safe, they, at length, become willing to run the risk of being less free." 38

To avoid this danger, Hamilton proposed a firm union and reliance on naval power. Hamilton assumed that without an energetic government, the American union would collapse. The states would then become a variety of more or less hostile land powers. The "perpetual menacings of danger" would oblige each state to be "always prepared to repel" invasion from its neighbors with armies numerous enough for instant defence. The result would be not only an arms race, but a race towards despotism. "The continual necessity for their services" would elevate the "importance of the soldier" and degrade the "condition of the citizen." Especially on the borders, citizens would grow accustomed to "frequent infringements on their rights" by the military which would "serve to weaken their sense of those rights." In time their free spirit would become slavish as they were "brought to consider the soldiery not only as their protectors, but as their superiors." Quite tragically, Americans would then "in a little time see established in every part of this country, the same engines of despotism which have been the scourge of the old world!"39

38. Federalist, 8: 45; Discourses, 1. 3: 201-202; 2. 25: 399; and 3. 1: 419-421. 39. Federalist, $8: 48$. 
There was one important exception to this Old World pattern; namely Great Britain, the greatest sea power of the eighteenth century. America was not England, but until England united, it was wracked by civil war, lived in constant danger of invasion, and had not yet produced the free spirit which insisted on the constitutional rule of law. If Americans were united under an energetic government with a powerful navy to keep danger at a distance, they could be at least as exceptional as England. Most citizens would feel safe from the perils of foreign and civil war. Then, there could rarely be a "pretext" for the large standing armies on their own territory which were necessary for land powers surrounded by hostile neighbors. The people would be in "no danger of being broken to military subordination." Because the laws would not relax to face military exigencies, the "civil state" could remain in "full vigor, neither corrupted nor confounded with the principles or propensities of the other state." The citizens would not be "habituated to look up to the military power for protection, or to submit to its oppressions." They would therefore "neither love nor fear the soldiery." As has been common in American history, the people would look at the military in a "spirit of jealous acquiescence in a necessary evil." When the power necessary to protect them from external danger was "exerted to the prejudice of their rights," they would "stand ready to resist it." Or perhaps better, since wars tend to panic most governments and peoples, the odds in favor of steady nerves and avoiding a military despotism were greatest if America became a great sea power which was able to project power abroad and avoided the necessity of large land forces on its own territory as much as possible. The foundation of American freedom would be the vigilant spirit of the people, but that spirit would arise from the security supplied by the energy and foresight of their government. ${ }^{40}$

40. Federalist, 8: 47-48. For an alternate view, which ignores the evidence of this essay and treats Hamilton as the leader of a militarist conspiracy, see Richard H. Kohn, The Eagle and the Sword: The Federalists and the Creation of the Military Establishment in America, 1783-1802 (New York: Free Press, 1975), pp. 252, 272-73, 284-86. Stanley Elkins and Eric McKitrick offer a slightly more balanced account in the Age of Federalism (Oxford: Oxford University Press, 1993), pp. 715-19. 
At least as much as ideology, this strategy of projecting naval power abroad may explain why the great sea powers of our century, the United States and England, remained free while great land powers surrounded by hostile neighbors, such as Germany, Russia, and China, never gained or soon lost their liberty. Machiavelli understood this strategy very well. The Italian cities which came closest to England's naval mastery were commercial Venice and Genoa. "Since [the Venetians] did not possess much territory on land, they employed their strength chiefly at sea, where they carried on their wars with great spirit, and made considerable acquisitions." Republican Venice and Genoa had done "wonderful things" with their commercial, maritime empires, and they were not confined simply to waging war. Why did Venice remain free for so long? Because commerce had destroyed the foundations of the agrarian feudal aristocracy. Venetian gentlemen were gentlemen "rather in name than in fact." They did not have "great incomes from landed possessions." Their riches were "based on trade and moveable property" and "none of them" had fortified castles to resist the republic. None had any independent "jurisdiction over men," and thus none was able develop an army of personal dependents. Citizens were thus able to defend themselves against the grandi. Machiavelli thus appears to have had a "Janus-face" which looked in two directions, one toward ancient Rome and the other toward the modern commercial republics of Italy. While some who followed the Florentine seized on the Roman model of combining military power and freedom, others would develop the Venetian model much further than Machiavelli and lay the foundations of modern universal liberty. ${ }^{41}$

\section{III}

Near the end of President Washington's second term, when many thought war with republican France was possible, Hamilton sketched a design for a Great Seal of the United States. The seal was to be a globe depicting Europe and a part of Africa, America,

41. See Pocock, Machiavellian Moment, pp. 210, 423, 495; The Prince 21: 91; Discourses, 1. 37: 272; Art of War, 1. 31-32; Locke's Second Treatise, 42: 297-98; Hume's "Of Refinement in the Arts," pp. 277-78; Wealth of Nations, 1: 401-02, 412; Hamilton at the New York Ratifying Convention, 27 June 1788, Papers, 5: 101; and Hamilton's Report on Manufactures, 10: 253-54. 
and the Atlantic Ocean. In the Old World, a "COLOSSUS," representing the French Directory, had one foot in Europe and another extending partly across the Atlantic towards America. It had a quintuple crown and a broken iron scepter in its right hand. It wore a pileus, or cap of liberty, but significantly, the cap was on backwards. A snake had wrapped itself around the staff of the scepter, as if it were in the act of strangling a label upon which was written, "Rights of Man.'" In the New World was Pallas Athena, representing the "Genius [or spirit] of America." She bore a "firm and composed countenance" and an "attitude of defiance." With a gold breast plate, a shield in one hand, and a spear in the other, she was capable of both offense and defense. Yet her genius was not the same as that of antiquity. Instead of the customary terrifying Medusa's head, her shield was engraved with the "scales of Justice" and her helmet encircled with olive wreaths. She also wore a radiated crown of glory, or halo, as a sign of providential interposition on behalf of America in its quarrel with the Jacobins. The allegory was meant to show that "though loving peace," the genius of America was "yet guided by Wisdom, or an enlightened sense of her own rights and interests." She was determined to exert her "valor, in breaking the scepter of the Tyrant." Hamilton believed it would improve the allegory to "represent the Ocean in a Tempest \& Neptune striking with his Trident the projected leg of the Colossus." Yet he also wondered if this addition would render the allegory too "complicated" to be readily understandable in America. It implied that sometimes Americans might have to cooperate with a less dangerous tyrant in order to deter or defeat a more dangerous one. ${ }^{42}$

42. See Hamilton's "Design for a Seal for the United States," May, 1796, Papers, 20: 208-09. Hamilton spent the last years of his career as an American Churchill warning of a gathering storm in Europe which might soon cross the sea to America. His warnings are not often taken seriously, in part because the French claimed to fight for liberty, and Hamilton's party committed many excesses (which Hamilton sought to prevent) in dealing with suspected Jacobins in America. Moreover, the French invasion did not materialize, at least not during Hamilton's watch. Yet Hamilton's fears were not without foundation. Napoleon did in fact try to send two military expeditions to New Orleans via Haiti in the administration of Thomas Jefferson, who dismantled the forces Hamilton built to confront the best troops of Europe. Fortunately, the courage of rebellious slaves and the persistence of malaria-carrying mosquitoes in Haiti inflicted so many casualties on the French expeditions that Jefferson was able to avoid the necessity of relying on his own arms. See Forrest McDonald, The Presidency of Thomas Jefferson (Lawrence, KS: University Press of Kansas, 1976), pp. 62-64. 
Much can be learned about Hamilton's relation to Machiavelli from this seal, especially if one focuses on its images of the Old World, the New World, and the Brave New World ushered in by the French Revolution. In 1776, Americans declared their independence from the tyrant of the sea, but how did the tyrannies of the Old World acquire their dominions? Hamilton had a very Machiavellian answer. Politically as well as geographically, the world could be divided into four parts, Europe, Asia, Africa, and America. "Unhappily for the other three, Europe, by her arms and by her negotiations, by [Machiavellian] force and by [Machiavellian] fraud," had in "different degrees extended her dominion over them all." Yet Athena was the patron goddess of the world's most famous democracy. Her scales of justice therefore had to be rooted in principles of human equality which were in tension with the "superiority" which Europe had long maintained over its dominions. That superiority "tempted her to plume herself the mistress of the world, and to consider the rest of mankind as created for her benefit." Facts had too long supported the "arrogant pretensions of the European." It belonged to the United States "to vindicate the honor" not simply of America, but of the "human race" itself. If Americans disdained to be "the instruments of European greatness," then they would have to confront the Machiavellian princes of Europe with overwhelming power. They would have to bind themselves together in a "strict and indissoluble Union," and also erect a "great American system," which would presumably include the rest of the Western Hemisphere after it had revolted against its masters. Led by the United States, that system would be "superior to the control of all transatlantic force or influence and able to dictate the terms of the connection between the old and the new world!" The seeds of the Monroe Doctrine are clearly latent in this passage, which calls for vindicating the doctrine of equal natural rights by resisting the Machiavellian imperialism of the Old World. ${ }^{43}$

The harshness of Old World practices, both domestically and within the European empires, made it difficult for most

43. Federalist, 11: 72-73. See also David Epstein, The Political Theory of the Federalist (Chicago: University of Chicago Press, 1984), 11-34. 
Americans not to be sympathetic toward the revolution in France. Hamilton shared those sympathies, but resisting an old tyranny is not the same as establishing a new free government. Sooner than most of his countrymen, Hamilton came to think that Americans and the French did not share the same principles. Indeed, their principles were diametrically opposed. In his sketch of the American seal, France wore the cap of liberty backwards, as if it had perverted its original cause by conquering and exploiting of much of Europe under the pretext of setting it free. The conduct of France was inconsistent with modern liberty, which is meant to be universal rather than the mere privilege of the strong. The universalization of liberty, that is, the doctrine of the rights of man, is virtually unthinkable without the preceding universal teaching of Christianity, which deliberately sought to limits wars of conquest and "rights" of the strong. "The praise of a civilized world," Hamilton claimed at the height of the French Revolution, "is justly due to Christianity." War, he claimed, "by the humane principles of that religion," which established the doctrine of just war, has "been stripped of half its horrors." When the French made war on Christianity itself, they allowed these horrors to return. Their republican revolution inspired religious passion without religion, or what we today would call patriotic and ideological fanaticism, a modern development which is not all that far from what Machiavelli intended when he sought to render religion more civil and patriotic. Whereas Machiavelli deplored Christianity for making us soft and dividing our loyalties between church and state, Hamilton defended it because it subjected the state to some law superior to the general will. Without some form of that subordination, the only law was the will of the strong. When the French "renounce[d] Christianity," they imitated the "same spirit of dominion which governed the ancient Romans," who believed they had "had a right to be Masters of the World and to treat the rest of Mankind as their vassals." They relapsed into "barbarism" and war resumed the "hideous and savage form which it wore in the ages of Roman and Gothic violence." Hamilton therefore claimed that "if there be anything solid in virtue," a time would come when it would be considered a "disgrace" for any partisan of the rights of man "to have 
advocated the Revolution in France in its later stages." ${ }^{44}$

Like Machiavelli, Hamilton was aware that throughout most of human history the moral price of liberty for some has been their dominion over others. In his first political pamphlet, Hamilton quoted David Hume, who was paraphrasing Machiavelli, in order to argue that free governments which are also mighty empires, such as England in 1775 and Rome before it, make the cruellest tyrants over their conquered provinces, which they exploit for their own benefit. Yet strategic necessity required Americans to unite and form their own empire to oppose the great empires of the old and new regimes of Europe. Could America be both a mighty empire and a new kind of republic which secured the rights of all members of the empire at the same time? Hamilton was not sure, but following David Hume again, he had some hope, a vision of a perfect commonwealth, or what Machiavelli might call an imaginary republic, a political "PRODIGY" of "reflection and choice" which could combine strength and size with the legitimacy which arises from the consent of the governed. An empire might also be a "representative democracy," a term Hamilton may well have been the first to coin. This term, and the determination to found a government on consent rather than crime, distinguish the principles (if not always the practice) of modern liberal from ancient or Machiavellian republics very well. The latter accept tyranny in their empires to secure the liberty of the stronger; the former aim to extend liberty throughout their empires in order to make them legitimate. To give Machiavelli his due, perhaps all government is some mixture of force, fraud, and consent, but so far as possible, Hamilton sought to render the American

44. See The Cause of France, 1794, Papers, 17: 585-86; The French Revolution, 1794, Papers, 17: 586-88; The War in Europe, September-December 1796, Papers, 20 : 339-40. Largely because modern ideological warfare does inspire passions rivalling religious fanaticism, Hamilton did not think it would be possible to combat the French effectively without attaching the passions of religion to constitutional government in America. He proposed forming a Christian Constitutional Society, which might have been a more dynamic alternative to the moribund Federalist Party and have become an American version of the Christian Democratic parties of Europe. Constitutional government would thus have become a kind of Machiavellian civil religion, but for the purposes of combatting the much uglier, atheistic civil religion of republican France. See Hamilton to Timothy Pickering, 22 March 1797, Papers, 20: 545; Hamilton to James A. Bayard, 16-21 April 1802, Papers, 25: 606; and Discourses, 1. 15: 234; II: 2, 330-31. 
empire legitimate by founding it on consent. "The fabric of the American empire," he claimed, "ought to rest on the solid basis of the consent of the people. The streams of national power ought to flow immediately from that pure, original fountain of all legitimate authority." For Hamilton at least, the only legitimate and effectual alternative to the Machiavellian politics of the ancient and new regimes of Europe was to republicanize the American empire. In principle at least, Hamilton's republican empire would be the moral antithesis of the imperious republics championed by Machiavelli. ${ }^{45}$

Was Alexander Hamilton a Machiavellian statesmen? Of necessity, the answer depends on the perspective employed. Fearing Machiavellian princes, Hamilton's opponents often wondered whether he gave enough due to consent and republican government. Fearing Machiavellian republics and empires, Hamilton often wondered if his opponents gave enough due to the necessity of energy even (or especially) in a republic. ${ }^{46} \mathrm{He}$ paid at least as much attention as Machiavelli to the necessity of strength in government and energy in the executive. Though rarely given credit for it, he had a subtle understanding of the relation between virtù and virtue: between effective, confidence-inspiring government and the public spirit of free citizens. Yet he also moralized Machiavelli's teaching by proposing a national bank, a professional citizen army, and a powerful commercial, maritime empire as ways to avoid the crime, despotism, and militarization of society (and virtue) which Machiavelli seemed to consider inseparable from republican warfare. Like Machiavelli, he sought to found a mighty empire, but unlike Machiavelli, he also sought to make it legitimate by republicanizing it. When it comes to waging war and remaining free at the same time, the American republican empire has been both more successful and more deserving of success than any other nation in history. The chief credit for this remarkable accomplishment belongs to Alexander Hamilton.

45. The Farmer Refuted, Papers, 1: 86-87; Hamilton to Gouveneur Morris, 19 May 1777, Papers, 1: 255; Federalist, 1: 3; Federalist, 22: 146; Federalist, 85: 594; The Stand, Papers, 21: 408; The Prince, 15: 61; 21: 88; Discourses, 1 Preface, 190; 2. 2: 333; and Hume's "Of the Original Contract" and "An Idea for a Perfect Commonwealth," pp. 21, 471, 525.

46. See Hamilton's speech of 18 June 1787, Papers, 4: 193, and Jefferson's notes on Hamilton's republican professions in "Conversation with Thomas Jefferson," 13 August 1791, Papers, 9: 33-34. 